Teologia Praktyczna 20(2019)

doi: $10.14746 /$ tp.2019.20.09

ORCID: 0000-0001-7379-6220

ORCID: 0000-0002-7695-4113

TOMASZ KORCZYŃSKI

JACEK ŚLIWAK

Katolicki Uniwersytet Lubelski Jana Pawła II

Instytut Psychologii

\title{
Religijność a postawa wobec kary śmierci
}

Religia występuje z różnym natężeniem i w różnej formie we wszystkich społeczeństwach naszego globu. Gdzie tylko pojawili się ludzie, tam rozwijała się religijność w postaci modlitwy, obrzędów oraz kultu. Jeden z czołowych przedstawicieli psychoanalizy humanistycznej, Erich Fromm, zauważa, że „nie było takiej kultury w przeszłości i nie może być takiej kultury w przyszłości, która nie miałaby religii” (za: Prokopiuk 1968, s. 134).

W literaturze z zakresu psychologii religii pojęcie „religia” jest zazwyczaj rozpatrywane $\mathrm{w}$ znaczeniu przedmiotowym i podmiotowym (Kuczkowski 1993, s. 22; Makselon 1990, s. 255). Religia rozumiana przedmiotowo oznacza zespół prawd, norm postępowania, czynności obrzędowych, instytucji wyjaśniających, a także regulujących stosunek osoby ludzkiej jako jednostki czy członka grupy społecznej do Boga. Podmiotowo rozumiana, wyraża się natomiast subiektywnym, indywidualnym i podmiotowym ustosunkowaniem się jednostki do systemu prawd z zaangażowaniem w to całej sfery osobowościowej człowieka. Analizując problematykę religijności, możemy zauważyć, że jest to rzeczywistość bogata i złożona. Aby uporządkować problematykę religijności oraz umożliwić jej pogłębioną analizę, psychologowie, odwołując się do różnych kryteriów, dokonują licznych podziałów oraz typologizacji. Celem takich typologizacji na gruncie psychologii religii jest poszukiwanie powiązań pomiędzy wyodrębnionymi wymiarami a czynnikami społecznymi, psychologicznymi czy też osobowościowymi (por. Śliwak 2005, s. 317). 
Postawa religijna jest jednym z podstawowych pojęć stosowanych w psychologii religii. Na gruncie polskim istnieje bardzo bogata tradycja badań nad religijnością w kontekście postawy (Prężyna 1973, 1981; Chaim 1991). Jest ona definiowana jako ,względnie stałe, pozytywne lub negatywne ustosunkowanie się (intelektualno-przekonaniowe, emocjonalno-motywacyjne i behawioralne) jednostki wobec nadprzyrodzoności” (Prężyna 1981, s. 45). Tak zdefiniowana postawa ma swoją strukturę, której komponenty tworzą - w zależności od swojej złożoności - mniej lub bardziej zwarty system.

Jaworski (1989) również analizuje religijność w kategorii postawy. Autor ten dokonuje bardzo ciekawej i owocującej licznymi badaniami empirycznymi typologizacji. Wyodrębnia dwa typy religijności: personalną i apersonalną. Religijność personalną definiuje jako ,,angażującą człowieka formę przeżywania jego kontaktu z Bogiem osobowym. Człowiek jako podmiot relacji religijnej w partnerskim dialogu z Bogiem angażuje całe swoje «ja» w bezpośrednie i aktualne spotkanie «Ty» Boga. W swoich aktach człowiek ten czuje się wolny i twórczy, świadomy swego celu i własnej chrześcijańskiej godności. Ma on świadomość, że tworzy swój stosunek do Boga i czuje się za to odpowiedzialny" (Jaworski 1989, s. 67). Religijność apersonalna jest natomiast traktowaniem Boga instrumentalnie, do zaspokajania swoich potrzeb. Kontakt z Bogiem ma formę jednostronnego monologu, formy religijności opierają się na naśladownictwie i mają cechy przesądów. Bóg i kontakt $\mathrm{z}$ nim nie są celem samym w sobie. Osoba w relacji z Bogiem często odczuwa przymus zewnętrzny, a kiedy brak tego przymuszania, związek jest bierny i obojętny.

Bronk (1996, s. 209) pisze, że na gruncie psychologii religijność człowieka możemy rozumieć jako „relacje i cechę aktów psychicznych skierowanych ku transcendentnemu religijnemu przedmiotowi. Religijność może być także opisywana jako relacja podmiotu do przedmiotu, którym jest personalny Bóg". Inni badacze zauważają, że wszystko to, co zachodzi, kiedy człowiek konfrontuje się z Bogiem, nie może zostać sprowadzone wyłącznie do zbioru twierdzeń odnoszących się do rzeczywistości transcendentnej, a stanowi żywą i przeżywaną w osobowy sposób relację (por. Kłoczkowski 2001; Chaim 1991, s. 16). Relacje międzyludzkie są bardzo podobne w swojej strukturze do relacji religijnych, a jedyną rzeczą pozwalającą je różnicować jest specyfika przedmiotu, do którego odnoszą się te drugie (por. Śliwak 1993; Jarosz 2003, s. 16). Ta specyficzność sprawia, że z psychologicznego punktu widzenia cechy relacji religijnej są trudne do zaobserwowania. Porównywanie relacji interpersonalnej stosowanej na gruncie psychologii społecznej z relacją religijną pozwala na głębszy psychologiczny opis jej natury.

Drugą zmienną interesującą nas w tym opracowaniu jest postawa wobec karty śmierci. Problematyka tej zmiennej jest rozpatrywana na gruncie wielu nauk. Do rozpoczęcia dyskusji na temat kary śmierci doszło dopiero 
w XVIII wieku, kiedy to Beccaria $(1959$, s. 127) bardzo ostro zaatakował ją w swoim dziele $O$ przestepstwach $i$ karach. Jego stanowisko nie jest jednak do końca spójne. Mimo iż twierdził, że społeczeństwo nie ma podstaw prawnych do stosowania kary śmierci, godził się na jej wykonywanie, a nawet uważał ją za konieczną w niektórych wypadkach. Na przykład w sytuacji, gdy przestępca umieszczony w więzieniu za wystąpienie przeciwko bezpieczeństwu państwa, może nadal stanowić zagrożenie dla społeczeństwa i narazić je na niebezpieczeństwo zarówno zewnętrzne, jak i wewnętrzne. Wraz z pojawieniem się negatywnego stanowiska wobec kary śmierci rozgorzała dyskusja na gruncie prawniczym i filozoficznym, która trwa do chwili obecnej. W tej dyskusji można wyróżnić dwa skrajne stanowiska. Pierwsze jest związane z obroną stosowania kary śmierci i to zarówno z prawniczego, jak i filozoficzno-etycznego punktu widzenia, a drugie stanowisko wiąże się z negacją stosowania kary śmierci. Zwolennicy stosowania kary śmierci, nazywani represjonistami lub retencjonalistami, postrzegają taką karę jako czynnik służący odstraszaniu potencjalnych przestępców poprzez wzbudzanie lęku związanego z możliwością pozbawienia życia (por. Bartula 1998 a, s. 37). Wiele badań prowadzonych na gruncie amerykańskim miało na celu potwierdzenia hipotezy, że kara śmierci odstrasza potencjalnych przestępców. Wyniki badań prowadzonych przez Isaaca Ehrlicha w 1975 roku wskazują, że wykonanie jednego wyroku ratuje życie ośmiu potencjalnym ofiarom (za: Donohue i Wolfers 2006, s. 792). Nowsze wyniki badań przeprowadzonych przez Dezhbakhsha i Shepherda wskazują na to, że jedna egzekucja ma znacznie większą siłę odstraszania niż ta, która wynikałaby z badań Ehrlicha. Badacze ci uzyskali spadek liczby dokonywanych morderstw o 0,05 na 100 tysięcy ludzi, co przekłada się na fakt, że jedna egzekucja to o 150 morderstw mniej, czyli 150 uratowanych istnień (za: Donohue i Wolfers 2006, s. 798). Przeciwne stanowisko w stosunku do retencjonalistów zajmują abolicjoniści. Postrzegają oni karę śmierci jako niehumanitarną, niemającą właściwości prewencyjnych, okrutną i niegodną społeczeństwa na tym poziomie rozwoju kulturalnego. Jako prekursora podejścia abolicyjnego wskazuje się Beccaria i jego krytyczne uwagi co do stosowania kary śmierci. W odwołaniu do tych argumentów, na gruncie zarówno europejskim, jak i amerykańskim rozwija się negatywne podejście do stosowania przez społeczeństwa kary śmierci. Stanowisko to obecne jest również na gruncie polskim. Do głównych reprezentantów tego nurtu należy zaliczyć nauki prawne (por. Grześkowiak 1982, 1988) oraz filozoficzno-etyczne (por. Szostek 1989; Chudy 1989). Badacze reprezentujący nurt abolicjonistyczny wykazują, że kara śmierci nie ma mocy prewencyjnej, czyli jej wykonywanie nie zmniejsza liczby popełnionych morderstw. Bailey i Peterson, stosując dwie strategie badawcze, polegające na porównywaniu liczby zabójstw w stanach, w których obowiązuje i nie obowiązuje kara śmierci, oraz w stanach, w których stosowa- 
no tę karę, ale została zniesiona, doszli do wniosku, że nie ma statystycznie istotnych różnic $\mathrm{w}$ zakresie popełnianych morderstw, co wiąże się $\mathrm{z}$ konkluzją, że nie ma ona odstraszającego waloru (za: Krahé 2005, s. 206). Na gruncie polskim nie ma głębszego zainteresowania problematyką postawy wobec kary śmierci. Jeżeli natomiast chodzi o badania amerykańskie i kanadyjskie nad postawami osób wobec takiej kary, to są one tam prowadzone już od 1982 roku. Brak zainteresowania polskich psychologów postawą wobec kary śmierci, spowodował, że autorzy niniejszego opracowania mieli problem ze zdefiniowaniem tej postawy. Przyjęto zatem, że jest to względnie stałe, pozytywne lub negatywne ustosunkowanie się (intelektualno-przekonaniowe, emocjonalno-motywacyjne i behawioralne) jednostki wobec kary śmierci.

Podstawowym celem analiz prezentowanych w tym artykule jest poszukiwanie powiązań pomiędzy religijnością a postawą wobec kary śmierci. Problem badawczy niniejszego opracowania jest bardzo ogólny i odnosi się do pytania: Czy istnieje zależność pomiędzy religijnością a postawą wobec kary śmierci? Aby sprecyzować ten problem, postawiono bardziej szczegółowe pytania: 1. Czy różne aspekty religijności wykazują powiązanie z postawą wobec kary śmierci? 2. Czy osoby mające negatywne relacje z Bogiem wykazują większą aprobatę dla kary śmierci niż osoby o pozytywnych relacjach? 3. Czy płeć osoby badanej różnicuje powiązania między analizowanymi zmiennymi?

$\mathrm{Z}$ tak postawionych pytań badawczych wysnuto następujące hipotezy:

H 1. Istnieje powiązanie pomiędzy religijnością a postawą wobec kary śmierci.

H 2. Wysoka intensywność pozytywnej postawy religijnej wiąże się z negatywną postawą wobec kary śmierci.

H 3. Religijność personalna wiąże się z brakiem akceptacji dla kary śmierci.

H 4. Negatywne relacje religijne wykazują powiązanie z pozytywną postawą wobec kary śmierci.

H 5. Płeć modyfikuje powyższe związki między analizowanymi zmiennymi.

W niniejszym opracowaniu przyjęto, że postawa wobec kary śmierci oraz poszczególne jej wymiary będą zmiennymi zależnymi, a religijność jednostki w różnych jej aspektach będzie zmienną niezależną. 


\section{Metoda i próbka}

W badaniach zastosowano cztery testy psychologiczne: Skalę Intensywności Postawy Religijnej - Władysława Prężyny, Skalę Relacji do Boga - Dirka Hutsebauta, Skalę Religijności Personalnej - Romualda Jaworskiego oraz Kwestionariusz Postaw wobec Kary Śmierci - w konstrukcji autorów artykułu.

Skala Intensywności Postawy Religijnej-skonstruowana przez Władysława Prężynę - składa się z 30 twierdzeń. Na każde twierdzenie osoba badana odpowiada na siedmiostopniowej skali typu Likerta. Wskaźnikiem liczbowym intensywności postawy religijnej jest suma punktów uzyskanych w poszczególnych odpowiedziach. Wysoki wynik oznacza wysoki poziom intensywności pozytywnej postawy religijnej, niski wynik wskazuje na wysoki poziom intensywności negatywnej postawy religijnej. Rzetelność Skali (r-Pearsona) wynosi $.98(\mathrm{~N}=70)$. Trafność narzędzia ustalono, odwołując się do kryteriów zewnętrznych i wewnętrznych. Obliczone współczynniki mieszczą się w granicach od .67 do .84 i wskazują na wysoką trafność testu (por. Prężyna 1968, 1981).

Skala Relacji do Boga. Dirk Hutsebaut, autor prezentowanej skali, zauważa, że dotychczasowe narzędzia do pomiaru postaw religijnych składają się z twierdzeń dotyczących akceptacji bądź odrzucenia religijnych dogmatów oraz twierdzeń, analizujących, jakie znaczenie ma religia w życiu człowieka czy w życiu całego społeczeństwa, a zatem badających poziom religijności. Komplementarna do dotychczasowych badań byłaby zatem analiza rzeczywistych relacji osoby wierzącej do Boga. Dla psychologa interesująca jest odpowiedź na pytanie, jak osoba przeżywa żywe relacje z Bogiem (por. Hutsebaut 1980, s. 46, Śliwak i Bartczuk 2011).

Nawiązując do powyższych myśli, Hutsebaut skonstruował skalę mierzącą relację do Boga. Konstrukcja tego narzędzia była ściśle empiryczna. Nie przyjmowano z góry założeń co do rodzaju istniejących relacji. Ostateczna wersja składa się z siedmiu podskal podstawowych i trzech dodatkowych ${ }^{1}$. W każdej podskali jest osiem twierdzeń ocenianych na siedmiostopniowej skali typu Likerta. Przy pomocy kompetentnych sędziów opisano każdą z podskal. Badany rodzaj relacji do Boga może być opisany w sposób następujący: 1. Zależność - człowiek odczuwa potrzebę pomocy Bożej, która jest konieczna dla jego istnienia, a Bóg jest widziany jako ktoś, kto daje istnienie. 2. Autonomia - odpowiedzialność człowieka wyrasta poprzez jego uniezależnienie się od normatywnej funkcji Boga. 3. Buntowniczość - Bóg nie spełnia pewnych oczekiwań, wyzwalając bunt ze strony proszącego. 4. Wina - Lęk - jednostka doświadcza poczucia winy i czuje się osądzana przez

\footnotetext{
${ }^{1} \mathrm{~W}$ prezentowanych badaniach użyto tylko siedmiu podskal podstawowych.
} 
Boga. 5. Identyfikacja - jednostka identyfikuje się z Jezusem Chrystusem jako idealnym człowiekiem i wzorem. 6. W spółh um anitarn ość - ukierunkowanie na Boga poprzez ukierunkowanie na człowieka. Bóg jest dostrzegany i odnajdywany w ludziach. 7. Norma etyczna - Bóg jest dostrzegany jako norma absolutna (por. Hutsebaut 1980; Śliwak i Szafrańska 2000; Śliwak i Bartczuk 2011).

Skala Religijności Personalnej (SRP) Romualda Jaworskiego. Narzędzie składa się ze 100 twierdzeń wyrażających religijność personalną i apersonalną. Przeprowadzono taksonomię wrocławską na grupie 100 osób (50 kobiet i 50 mężczyzn) z wykształceniem średnim i wyższym w wieku powyżej 25 lat w celu sprawdzenia, czy opracowana skala jest jednowymiarowa, czy też można wyróżnić w niej wymiary szczegółowe. Wyniki otrzymane po analizie pozwoliły stwierdzić, że skala SRP jest homogeniczna (por. Jaworski 1989, s. 81-82). Skala SRP została także sprawdzona pod względem jej trafności wewnętrznej, poprzez analizę logiczną treści pytań pod kątem ich reprezentatywności do badanej rzeczywistości przy pomocy sędziów kompetentnych. Rzetelność Skali Religijności Personalnej zbadano metodą retestu na grupie 80 studentów, gdzie okres pomiędzy badaniami wyniósł 14 dni. Uzyskany wskaźnik korelacji (r-Pearsona) dla całej skali wyniósł $\mathrm{r}=0,86$ (por. Jaworski 1989, s. 83-84).

Kwestionariusz Postaw Wobec Kary Śmierci (PWKS). Zebrano około 100 twierdzeń dotyczących kary śmierci, następnie dołączono do nich pięciostopniową skalę odpowiedzi od 1-zdecydowanie się nie nadaje do 5 - zdecydowanie się nadaje i poproszono 30 sędziów kompetentnych, aby ocenili, na ile dane twierdzenia nadają się do pomiaru postawy wobec kary śmierci. W wyniku tego zabiegu usunięto 76 niediagnostycznych twierdzeń. Sędziowie kompetentni zauważyli także, że pozostałe 24 twierdzenia można podzielić na cztery wymiary. Wymiary te, po dyskusji, zostały nazwane: 1 . Poprawa przestępcy (PP). 2. Aspekt profilaktyczny (AP). 3. Zadośćuczynienie społeczeństwu (ZS). 4. Aspekt moralny (AM). Uzyskanym wymiarom zostały także przypisane definicje: 1. Poprawa przestępcy (PP) - zmiana zachowania przestępcy, uświadomienie mu popełnionego przewinienia oraz utrwalenie wywołanych zmian. 2. Aspekt profilaktyczny (AP) - popełnienie przestępstwa niesie ze sobą odpowiednią karę i jej obawa jest przesłanką, która wstrzymuje człowieka od popełnienia czynu zabronionego. 3. Zadośćuczynienie społeczeństwu (ZS) - odpłata społeczeństwu za wyrządzone krzywdy z jednoczesnym dążeniem do sprawiedliwego karania osób, które naruszyły porządek społeczny. 4. Aspekty moralny (AM) - światopogląd osoby w zakresie kary śmierci, jej stosowalności oraz skutków jej wykonywania, a także stosunek wyznawanej przez człowieka wiary w karę śmierci . Każdy z wymieniowych wymiarów może być samodzielnie interpretowany. Aby to umożliwić, należy zsumować odpowiedzi na pytania wchodzące w jego skład. 
Po tym zabiegu do skali zostały dołączone odpowiedzi od 1 - zdecydowanie się nie zgadzam, do 7 - zdecydowane się zgadzam. Osoba, odpowiadając na dane twierdzenie, ma możliwość wyrażenia swojej aprobaty lub dezaprobaty poprzez zakreślenie odpowiedniej cyfry. Wynik ogólny pomiaru (PWKS WO) uzyskuje się poprzez zsumowanie odpowiedzi na wszystkie pytania. Mieści się on w granicach od 24 (zdecydowanie przeciwko karze śmierci) do 168 (zdecydowanie za karą śmierci). Rzetelność Kwestionariusza PWKS sprawdzono metodą retestu. Badaniu poddano grupę 70 osób (studentów III, IV i V roku psychologii), a następnie badanie powtórzono po upływnie 14 dni. Współczynnik korelacji (r-Pearsona) dla PWKS wyniósł 0.808 .

Badaniem objęto osoby mieszkające na terenie Stalowej Woli i Rzeszowa oraz ich okolic. Ogółem przebadano 100 osób: 55 kobiet oraz 45 mężczyzn, co stanowiło 45\%. Średni wiek badanej próbki $\mathrm{M}=31,59(\mathrm{SD}=9,01)$, a w przypadku grupy kobiet $\mathrm{M}=31,04(\mathrm{SD}=9,38)$ oraz mężczyzn $\mathrm{M}=32,27$ $(\mathrm{SD}=8,59)$. Rozpiętość wiekowa w grupie zasadniczej wynosi od 23 do 54 lat. Najwięcej było osób z wykształceniem średnim (37\%), następnie z wykształceniem wyższym (25\%), a trzecią grupę stanowiły osoby z licencjatem $(23 \%)$. Najmniej reprezentowaną grupą były osoby z niepełnym wyższym wykształceniem (15\%).

\section{Analiza uzyskanych wyników}

Analiza wyników została poprowadzona tak, aby opisać powiązania pomiędzy poszczególnymi typami religijności a postawą wobec kary śmierci. Wyniki przedstawiono kolejno w nawiązaniu do ogólnej postawy wobec kary śmierci oraz jej poszczególnych wymiarów wyodrębnionych za pomocą Kwestionariusza Postaw Wobec Kary Śmierci (PWKS).

\section{Postawa wobec kary śmierci - wynik ogólny (PWKS - WO)}

Ogólna postawa wobec kary śmierci wykazuje istotne powiązania z trzema rodzajami relacji do Boga (por. tab. 1). Powiązania te są w tych trzech przypadkach pozytywne i dotyczą takich relacji, jak: autonomia, buntowniczość oraz wina - lęk. Najwyższy dodatni współczynnik korelacji odnotowano w przypadku relacji buntowniczość $(\mathrm{r}=, 318 ; \mathrm{p}<.001)$. Oznacza to, że im osoba uzyskuje wyższe wyniki w relacji buntowniczość, tym wyższy jest również jej wynik w ogólnej postawie wobec kary śmierci. Do grona osób, które będą pozytywnie nastawione do kary śmierci, należą również osoby przeżywające relacje wina - lęk $(\mathrm{r}=, 309 ; \mathrm{p}<.002)$. Można zatem wywnioskować, że oso- 
by odczuwające lęk wobec Boga będą skłonne do akceptowania kary śmierci. $\mathrm{Z}$ tego iż relacja autonomia również pozytywnie koreluje z ogólną postawą wobec kary śmierci $(r=, 276 ; \mathrm{p}<.001)$, można wysnuć wniosek, że im wyższa jest chęć uniezależnienia się od normatywnej funkcji Boga, tym bardziej taka osoba postrzega karę śmierci jako niezbędną formę karania przestępców.

Tabela 1. Współczynnik korelacji (r-Pearsona) (PWKS - WO) z typami religijności: w całej badanej populacji $(n=100)$ oraz w podgrupach kobiet $(n=55)$ i mężczyzn $(\mathrm{n}=45)$

\begin{tabular}{|l|c|c|c|c|c|}
\hline \multirow{2}{*}{ Religijność } & \multicolumn{5}{|c|}{ Postawa wobec Kary Śmierci - Wynik Ogólny } \\
\cline { 2 - 6 } & Grupa zasadnicza & \multicolumn{2}{|c|}{$\mathrm{K}$} & $\mathrm{M}$ \\
\cline { 2 - 6 } & $\mathrm{r}$ & $\mathrm{p}$ & $\mathrm{R}$ & $\mathrm{P}$ & $\mathrm{r}$ \\
\hline Intensywnośćc &,- 125 & $\mathrm{n} . \mathrm{i}$ & $\mathbf{- , 3 7 2}$ & $\mathbf{. 0 0 5}^{* *}$ &, 081 \\
\hline Relig. personalna &,- 157 & $\mathrm{n} . \mathrm{i}$ &,- 198 & $\mathrm{n} . \mathrm{i}$ &,- 052 \\
\hline Zależność &,- 018 & $\mathrm{n} . \mathrm{i}$ &,- 130 & $\mathrm{n} . \mathrm{i}$ &, 176 \\
\hline Autonomia & $\mathbf{2 7 6}$ & $\mathbf{. 0 0 5}^{* *}$ &, 254 & $\mathrm{n} . \mathrm{i}$ &, 264 \\
\hline Buntowniczośćc & $\mathbf{3 1 8}$ & $\mathbf{. 0 0 1}^{* *}$ & $\mathbf{3 2 3}$ & $\mathbf{. 0 1 6}$ &, 290 \\
\hline Wina-Lęk & $\mathbf{3 0 9}$ & $\mathbf{. 0 0 2}^{* *}$ & $\mathbf{4 0 0}$ & $\mathbf{. 0 0 2}$ &, 202 \\
\hline Identyfikacja &, 053 & $\mathrm{n} . \mathrm{i}$ &, 050 & $\mathrm{n} . \mathrm{i}$ &, 086 \\
\hline Wspóthumanitarnośćc &,- 008 & $\mathrm{n} . \mathrm{i}$ &,- 100 & $\mathrm{n} . \mathrm{i}$ &, 133 \\
\hline Norma etyczna &, 062 & $\mathrm{n} . \mathrm{i}$ &, 006 & $\mathrm{n} . \mathrm{i}$ &, 172 \\
\hline
\end{tabular}

$* \mathrm{p}<.05 * * \mathrm{p}<.01$

Podobny obraz powiązań między analizowanymi zmiennymi pojawia się $\mathrm{w}$ podgrupie kobiet, $\mathrm{z}$ tą tylko różnicą, że najsilniejsze powiązanie pomiędzy ogólną postawą wobec kary śmierci a relacjami religijnymi odnotowano $\mathrm{w}$ przypadku wina - lęk $(\mathrm{r}=0,400 ; \mathrm{p}<.002)$. Za interesujące należy uznać to, że $\mathrm{w}$ grupie kobiet oprócz wymienionych relacji religijnych $\mathrm{z}$ ogólną postawą koreluje, ale negatywnie, intensywność postawy religijnej $(\mathrm{r}=-, 372 ; \mathrm{p}<.005)$. Możemy zatem wywnioskować, że kobiety charakteryzujące się wysoką intensywnością pozytywnej postawy religijnej będą miały negatywne nastawienie wobec stosowania kary śmierci. Charakterystyczny jest brak istotnych statystycznie powiązań pomiędzy ogólną postawą wobec kary śmierci a typami religijności w podgrupie mężczyzn. 


\section{Religijność a poprawa przestępcy (PP)}

W dalszym etapie, po omówieniu ogólnej postawy wobec kary śmierci, zajęto się analizą wyodrębnionych wymiarów tej postawy. Pierwszym wymiarem, na który zwrócono uwagę, była poprawa przestępcy (PP) (por. tab. 2). Wyniki pokazują, że tylko dwa typy religijności: buntowniczość $(\mathrm{r}=, 238$; $\mathrm{p}<.004)$ oraz wina - lęk $(\mathrm{r}=, 218 ; \mathrm{p}<.029)$ korelują istotnie statystycznie $\mathrm{z}$ wymiarem poprawa przestepcy i są to korelacje pozytywne. Osoby, które zatem buntują się przeciwko Bogu, będą postrzegały wykonywanie kary śmierci jako czynnik służący uświadomieniu przestępcy, że popełnił przewinienie. Osoby, których relacja do Boga jest nacechowana poczuciem winy i lęku, podobnie jak osoby buntownicze, będą postrzegały karę śmierci jako skuteczny środek zmieniający zachowanie przestępcy.

Tabela 2. Współczynnik korelacji (r-Pearsona) poprawa przestępcy (PP) z typami religijności: $\mathrm{w}$ całej badanej populacji $(\mathrm{n}=100)$ oraz $\mathrm{w}$ podgrupach kobiet $(\mathrm{n}=55)$ i mężczyzn $(\mathrm{n}=45)$

\begin{tabular}{|l|c|c|c|c|c|}
\hline \multirow{2}{*}{ Religijność } & \multicolumn{5}{|c|}{ Poprawa przestępcy (PP) } \\
\cline { 2 - 6 } & Grupa zasadnicza & \multicolumn{2}{|c|}{$\mathrm{K}$} & $\mathrm{M}$ \\
\cline { 2 - 6 } & $\mathrm{r}$ & $\mathrm{p}$ & $\mathrm{r}$ & $\mathrm{P}$ & $\mathrm{r}$ \\
\hline Intensywność &,- 145 & $\mathrm{n} . \mathrm{i}$ & $\mathbf{- , 3 0 0}$ & $\mathbf{. 0 2 6}^{*}$ &,- 087 \\
\hline Relig. personalna &,- 174 & $\mathrm{n} . \mathrm{i}$ &,- 103 & $\mathrm{n} . \mathrm{i}$ &,- 230 \\
\hline Zależność &,- 003 & $\mathrm{n} . \mathrm{i}$ &,- 050 & $\mathrm{n} . \mathrm{i}$ &, 022 \\
\hline Autonomia &, 153 & $\mathrm{n} . \mathrm{i}$ &, 203 & $\mathrm{n} . \mathrm{i}$ &, 150 \\
\hline Buntowniczość & $\mathbf{2 8 3}$ & $\mathbf{. 0 0 4} 4^{* *}$ & $\mathbf{, 3 0 3}$ & $\mathbf{. 0 2 4}$ &, $\mathbf{2 9 6}$ \\
\hline Wina-Lęk & $\mathbf{2 1 8}$ & $\mathbf{. 0 2 9}$ & $\mathbf{3 2 2}$ & $\mathbf{. 0 1 6}$ &, 140 \\
\hline Identyfikacja &,- 054 & $\mathrm{n} . \mathrm{i}$ &, 102 & $\mathrm{n} . \mathrm{i}$ &,- 234 \\
\hline Wspóthumanitarność &,- 098 & $\mathrm{n} . \mathrm{i}$ &,- 085 & $\mathrm{n} . \mathrm{i}$ &,- 132 \\
\hline Norma etyczna &,- 030 & $\mathrm{n} . \mathrm{i}$ &, 054 & $\mathrm{n} . \mathrm{i}$ &,- 128 \\
\hline
\end{tabular}

$* \mathrm{p}<.05 * * \mathrm{p}<.01$

Podobne wyniki jak grupa zasadnicza uzyskuje podgrupa kobiet, ale otrzymane współczynniki korelacji w relacjach religijnych buntowniczość oraz wina - lęk są wyższe. Można zatem wywnioskować o mocniejszym niż w przypadku grupy zasadniczej powiązaniu tych dwóch typów relacji religijnych $\mathrm{z}$ wymiarem poprawa przestępcy. W podgrupie kobiet, oprócz dwóch wymienionych relacji, pojawiło się jeszcze dodatkowe powiązanie, a dotyczy 
ono intensywności postawy religijnej, która koreluje negatywnie i istotnie statystycznie $(\mathrm{r}=-, 300 ; \mathrm{p}<0.26) \mathrm{z}$ wymiarem poprawa przestępcy. Pozwala to wywnioskować, że wraz ze wzrostem intensywności pozytywnej postawy religijnej u kobiet, spada pozytywne zapatrywanie się na karę śmierci. W podgrupie mężczyzn jedyną relacją, która wykazuje powiązanie z wymiarem poprawa przestępcy, jest buntowniczość $(\mathrm{r}=, 296 ; \mathrm{p}<0.49)$.

\section{Religijność a aspekt profilaktyczny (AP).}

Kolejnym wymiarem postawy wobec kary śmierci jest aspekt profilaktycz$n y$. Wyniki analizy korelacyjnej zarówno $\mathrm{w}$ grupie zasadniczej, jak i grupie kobiet i mężczyzn zaprezentowano w tabeli 3.

Tabeli 3. Współczynnik korelacji (r-Pearsona) aspekt profilaktyczny (AP) z typami religijności: $\mathrm{w}$ całej badanej populacji $(\mathrm{n}=100)$ oraz $\mathrm{w}$ podgrupach kobiet $(\mathrm{n}=55)$ i mężczyzn $(\mathrm{n}=45)$

\begin{tabular}{|c|c|c|c|c|c|}
\hline \multirow{3}{*}{ Religijność } & \multicolumn{5}{|c|}{ Aspekt profilaktyczny (AP) } \\
\hline & \multicolumn{2}{|c|}{ Grupa zasadnicza } & \multicolumn{2}{|c|}{$\mathrm{K}$} & M \\
\hline & $\mathrm{r}$ & $\mathrm{p}$ & $\mathrm{r}$ & $\mathrm{p}$ & $\mathrm{r}$ \\
\hline Intensywność &, 032 & n.i &,- 361 & $.007^{* *}$ & ,304 \\
\hline Relig. personalna &,- 007 & n.i &,- 178 & n.i & ,210 \\
\hline Zależność & ,132 & n.i &,- 093 & n.i & , 408 \\
\hline Autonomia & ,254 & $.011^{*}$ & ,279 & $.039^{*}$ & ,231 \\
\hline Buntowniczość & ,216 & $.031^{*}$ & ,320 & $.017^{*}$ & , 108 \\
\hline Wina - Lęk & ,297 & $.003^{* * *}$ & ,451 & $.001^{* *}$ & ,145 \\
\hline Identyfikacja & ,218 & $.029^{*}$ & ,092 & n.i & ,358 \\
\hline Wspóthumanitarność & 197 & $.049^{*}$ &,- 041 & n.i & ,436 \\
\hline Norma etyczna & ,230 & $.022^{*}$ &, 052 & n.i & ,445 \\
\hline
\end{tabular}

$* \mathrm{p}<.05 * * \mathrm{p}<.01$

Wymiar aspekt profilaktyczny wykazuje istotne powiązana z sześcioma mierzonymi typami relacji do Boga. Wszystkie powiązania mają charakter pozytywny. Najwyższy, dodatni, współczynnik korelacji odnotowano w przypadku relacji wina - lęk $(\mathrm{r}=, 297$; $\mathrm{p}<.003)$, co oznacza, że im osoba uzyskuje wyższe wyniki w tym rodzaju relacji, tym wyższe są również wyniki w tym wymiarze kary śmierci, jakim jest aspekt profilaktyczny. Osoby, które 
uniezależniają się od normatywnej funkcji Boga, a co się z tym wiąże - poszukują własnego systemu norm i wartości (autonomia $\mathrm{r}=, 254 ; \mathrm{p}<.011$ ), również będą widziały sens stosowana kary śmierci, gdyż ma ona służyć profilaktyce zachowań przestępczych. Także relacja buntowniczość wykazuje pozytywne korelacje $\mathrm{z}$ wymiarem aspekt profilaktyczny $(\mathrm{r}=, 216 ; \mathrm{p}<.031)$. Za charakterystyczne należy uznać to, że również trzy ostatnie z mierzonych relacji religijnych, tj. identyfikacja, wspóthumanitarność oraz norma etyczna, wykazują pozytywne korelacje z wymiarem aspekt profilaktyczny. Najwyższy dodatni współczynnik korelacji w tej grupie odnotowano w relacji norma etyczna $(\mathrm{r}=, 230 ; \mathrm{p}<.022)$. Uzyskany wynik pozwala stwierdzić, że gdy wzrasta u człowieka postrzeganie Boga jako ostatecznej normy moralnej, kara śmierci w oczach takiej osoby zaczyna mieć coraz wyższą wartość profilaktyczną i odstraszającą. Podobnie jest w przypadku, kiedy osoba identyfikuje się z Jezusem Chrystusem jako idealnym człowiekiem i wzorem do naśladowania (identyfikacja, $\mathrm{r}=, 218 ; \mathrm{p}<.029$ ). Również relacja wspóthumanitarność wykazuje pozytywne powiązanie z wymiarem aspekt profilaktyczny $(\mathrm{r}=, 197$; $\mathrm{p}<.049$ ). Możemy zatem wywnioskować, że kiedy Bóg jest dostrzegany i odnajdywany w innych ludziach, wtedy taka osoba postrzega karę śmierci jako czynnik wpływający pozytywnie na zmniejszenie liczby popełnianych przestępstw.

Bardzo charakterystyczne fakty pojawiły się, kiedy analizie poddano dwie grupy szczegółowe (kobiet i mężczyzn). W obu przypadkach wykazano powiązania $\mathrm{z}$ czterem mierzonymi typami religijności. W podgrupie kobiet powiązania pozytywne $\mathrm{z}$ relacjami autonomia $(\mathrm{r}=, 279 ; \mathrm{p}<.039)$, buntowniczość $(\mathrm{r}=, 320 ; \mathrm{p}<.017)$ oraz wina - lęk $(\mathrm{r}=, 451 ; \mathrm{p}<.001)$, a także negatywne powiązanie $\mathrm{z}$ intensywnościa postawy religijnej $(\mathrm{r}=-, 361 ; \mathrm{p}<.007)$. W podgrupie mężczyzn wszystkie powiązania miały natomiast charakter pozytywny, a postawa wobec kary śmierci w aspekcie profilaktycznym łączyła się z intensywnościa postawy religijnej $(\mathrm{r}=, 304 ; \mathrm{p}<.042)$ oraz relacjami: identyfikacja $(\mathrm{r}=, 358 ; \mathrm{p}<.009)$, wspóthumanitarnościa $(\mathrm{r}=, 436 ; \mathrm{p}<.003)$ oraz norma etyczna $(\mathrm{r}=, 445 ; \mathrm{p}<.002)$. Można zatem wysnuć wniosek, że u kobiet, wraz ze wzrostem intensywności pozytywnej postawy religijnej, spada akceptacja dla kary śmierci jako czynnika służącego profilaktyce. U mężczyzn natomiast sytuacja jest odwrotna, kiedy wzrasta intensywność postawy religijnej, wzrasta także postrzeganie kary śmierci jako wartościowej z punktu widzenia profilaktyki.

\section{Religijność a zadośćuczynienie spoleczeństwu (ZS)}

Wymiar zadośćuczynienie społeczeństwu wykazuje istotne powiązania z trzema relacjami religijnymi: autonomia, buntowniczość oraz wina - lęk 
(tab. 4). Wszystkie mają charakter pozytywny, co oznacza, że im osoba uzyskuje wyższe wyniki w tych trzech typach religijności, tym wyższe są również jej wyniki w wymiarze zadośćuczynienie społeczeństwu. Autonomia $(\mathrm{r}=, 280$; $\mathrm{p}<.005)$ i buntowniczość $(\mathrm{r}=, 278 ; \mathrm{p}<.005)$ odnotowują zbliżone do siebie wartości współczynnika korelacji. Podobną rolę przypisują tej karze osoby, których relacja do Boga jest nacechowana winą oraz poczuciem lęku wobec Niego $(r=, 245 ; p<.014)$.

Tabela 4. Współczynnik korelacji (r-Pearsona) zadośćuczynienie społeczeństwu (ZS) $\mathrm{z}$ typami religijności: $\mathrm{w}$ całej badanej populacji $(\mathrm{n}=100)$ oraz w podgrupach kobiet $(\mathrm{n}=55)$ i mężczyzn $(\mathrm{n}=45)$

\begin{tabular}{|l|c|c|c|c|c|}
\hline \multirow{2}{*}{ Religijność } & \multicolumn{5}{|c|}{ Zadośćuczynienie społeczeństwu (ZS) } \\
\cline { 2 - 6 } & Grupa zasadnicza & \multicolumn{2}{|c|}{$\mathrm{K}$} & $\mathrm{M}$ \\
\cline { 2 - 6 } & $\mathrm{r}$ & $\mathrm{p}$ & $\mathrm{R}$ & $\mathrm{p}$ & $\mathrm{r}$ \\
\hline Intensywnośćc &,- 094 & $\mathrm{n} . \mathrm{i}$ & $-\mathbf{4 3 0}$ & $\mathbf{, 0 0 1}^{* *}$ &, 190 \\
\hline Relig. personalna &,- 155 & $\mathrm{n} . \mathrm{i}$ & $\mathbf{- , 3 0 2}$ & $\mathbf{, 0 2 5}^{*}$ &, 101 \\
\hline Zależność &, 016 & $\mathrm{n} . \mathrm{i}$ &,- 201 & $\mathrm{n} . \mathrm{i}$ & $\mathbf{3 5 6}$ \\
\hline Autonomia & $\mathbf{2 8 0}$ & $\mathbf{, 0 0 5}^{* *}$ & $\mathbf{, 3 7 0}$ & $\mathbf{, 0 0 5}^{* *}$ &, 105 \\
\hline Buntowniczośćc & $\mathbf{2 7 8}$ & $\mathbf{, 0 0 5}$ & $\mathbf{3 4 *}$ & $\mathbf{, 0 1 0}^{* *}$ &, 170 \\
\hline Wina-Lęk & $\mathbf{2 4 5}$ & $\mathbf{, 0 1 4}$ & $\mathbf{3 5 8}$ & $\mathbf{, 0 0 7}^{* *}$ &, 107 \\
\hline Identyfikacja &, 039 & $\mathrm{n} . \mathrm{i}$ &,- 037 & $\mathrm{n} . \mathrm{i}$ &, 180 \\
\hline Wspóthumanitarność &, 030 & $\mathrm{n} . \mathrm{i}$ &,- 168 & $\mathrm{n} . \mathrm{i}$ &, 289 \\
\hline Norma etyczna &, 040 & $\mathrm{n} . \mathrm{i}$ &,- 097 & $\mathrm{n} . \mathrm{i}$ &, 260 \\
\hline
\end{tabular}

${ }^{*} \mathrm{p}<, 05 * * \mathrm{p}<, 01$

Podczas analizowania powiązań $\mathrm{w}$ grupach szczegółowych można zauważyć pewne prawidłowości. W podgrupie kobiet powiązania $\mathrm{z}$ wymiarem zadośćuczynienie społeczeństwu są obecne w przypadku trzech relacji (autonomia, buntowniczość oraz wina - lęk) i są to powiązania pozytywne oraz w przypadku intensywności postawy religijnej, a także religijności personalnej, gdzie są to powiązania negatywne. Można zatem wywnioskować, że wraz ze wzrostem intensywności pozytywnej postawy religijnej $(r=-, 430$; $\mathrm{p}<.001$ ), spada postrzeganie kary śmierci jako skutecznego czynnika służącego odpłacie społeczeństwu za wyrządzone krzywdy. Podobnie gdy religijność kobiet charakteryzuje się zaangażowaniem, spontanicznością, odpowiedzialnością $(\mathrm{r}=-, 302 ; \mathrm{p}<.025)$, wtedy negatywnie oceniają one karę śmierci jako formę zadośćuczynienia społeczeństwu oraz przywrócenia mu ładu i porządku 
społecznego. W przypadku zaś, kiedy relacje religijne do Boga mają charakter autonomiczny, buntowniczy czy też charakteryzują się poczuciem winy i lęku, mamy do czynienia z preferowaniem przez takie kobiety kary śmierci jako formy retrybucji oraz środka do osiągnięcia sprawiedliwości. W grupie mężczyzn natomiast wymiar zadośćuczynienie społeczeństwu wykazuje pozytywne powiązanie $\mathrm{z}$ relacją zależność $(\mathrm{r}=, 356 ; \mathrm{p}<.016)$.

\section{Aspekt moralny (AM)}

Z analizy korelacyjnej można wywnioskować, że ostatni wymiar postawy wobec kary śmierci - aspekt moralny - wykazuje powiązania z siedmioma $\mathrm{z}$ dziewięciu mierzonych typów religijności (tab. 5). Tylko w jednym przypadku powiązanie to ma charakter pozytywny, a w pozostałych przypadkach związek ten ma charakter negatywny. Najwyższy ujemny współczynnik korelacji odnotowano w przypadku relacji zależność $(\mathrm{r}=-, 462 ; \mathrm{p}<.000)$. Analizując uzyskane wyniki, można wywnioskować, że osoby, które w swoim życiu odczuwają potrzebę Bożej pomocy oraz postrzegają Boga jako Tego, który daje istnienie, $\mathrm{z}$ moralnego punktu widzenia nie potrafią w swojej wierze znaleźć argumentów pozwalających na zastosowanie najwyższego wymiaru kary. Osoby reprezentujące wysoką intensywność pozytywnej postawy religijnej $(\mathrm{r}=-, 425 ; \mathrm{p}<.000) \mathrm{w}$ połączeniu $\mathrm{z}$ aktywnością $\mathrm{w}$ relacjach z Bogiem, zaangażowaniem, spontanicznością, odpowiedzialnością, poczuciem godności chrześcijańskiej, postrzeganiem Boga jako wartości ostatecznej oraz centralnej, a przy tym z otwartością na nowe wiadomości i doświadczenia $(r=-, 408$; $\mathrm{p}<.000)$, podobnie jak osoby odczuwające zależność wobec Boga, nie są w stanie moralnie i etycznie uzasadnić jej stosowania. Karę śmierci za moralnie i etycznie niesłuszną uważają także osoby, które dostrzegają i odnajdują Boga w innych ludziach $(\mathrm{r}=-, 499 ; \mathrm{p}<.000)$ i dla których Bóg jest absolutną normą moralną, a swoje działanie podporządkowują Bożym nakazom i zakazom $(\mathrm{r}=-, 364 ; \mathrm{p}<.000)$, oraz które identyfikują się z Jezusem Chrystusem jako idealnym człowiekiem i wzorem do naśladowania $(\mathrm{r}=-, 327 ; \mathrm{p}<.001)$. Natomiast osoby, których relacja do Boga jest nacechowana krytycznym i buntowniczym ustosunkowaniem się do Stwórcy $(\mathrm{r}=, 319 ; \mathrm{p}<.001)$, nie mają problemów, aby znaleźć wystarczające, zarówno z moralnego, jak i etycznego punktu widzenia, argumenty przemawiające za stosowaniem kary śmierci. 
Tabela 5. Współczynnik korelacji (r-Pearsona) aspekt moralny (AM) z typami religijności: $\mathrm{w}$ całej badanej populacji $(\mathrm{n}=100)$ oraz w podgrupach kobiet $(\mathrm{n}=55)$ i mężczyzn $(\mathrm{n}=45)$

\begin{tabular}{|l|c|c|c|c|c|}
\hline \multirow{2}{*}{ Religijność } & \multicolumn{5}{|c|}{ Aspekt moralny (AM) } \\
\cline { 2 - 6 } & \multicolumn{2}{|c|}{$\mathrm{K}+\mathrm{M}$} & \multicolumn{2}{c|}{$\mathrm{K}$} & $\mathrm{M}$ \\
\cline { 2 - 6 } & $\mathrm{R}$ & $\mathrm{P}$ & $\mathrm{r}$ & $\mathrm{P}$ & $\mathrm{r}$ \\
\hline Intensywność & $\mathbf{- , 4 2 5}$ & $\mathbf{, 0 0 0}^{* *}$ &,- 148 & $\mathrm{n} . \mathrm{i}$ & $\mathbf{- , 4 7 1}$ \\
\hline Relig. personalna & $\mathbf{- , 4 0 8}$ & $\mathbf{, 0 0 0}^{* *}$ &,- 128 & $\mathrm{n} . \mathrm{i}$ & $\mathbf{- , 5 2 9}$ \\
\hline Zależność & $\mathbf{- , 4 6 2}$ & $\mathbf{, 0 0 0}^{* *}$ &,- 202 & $\mathrm{n} . \mathrm{i}$ & $\mathbf{- , 5 9 7}$ \\
\hline Autonomia &, 164 & $\mathrm{n} . \mathrm{i}$ &,- 134 & $\mathrm{n} . \mathrm{i}$ &, 205 \\
\hline Buntowniczośćc & $\mathbf{, 3 1 9}$ & $\mathbf{, 0 0 1}^{* *}$ &, 081 & $\mathrm{n} . \mathrm{i}$ & $\mathbf{3 9 4}$ \\
\hline Wina-Lęk &, 158 & $\mathrm{n} . \mathrm{i}$ &, 057 & $\mathrm{n} . \mathrm{i}$ &, 184 \\
\hline Identyfikacja & $\mathbf{- , 3 2 7}$ & $\mathbf{, 0 0 1}^{* *}$ &,- 114 & $\mathrm{n} . \mathrm{i}$ & $\mathbf{- , 4 7 8}$ \\
\hline Wspóthumanitarność & $\mathbf{- , 4 9 9}$ & $\mathbf{, 0 0 0}^{* *}$ &,- 198 & $\mathrm{n} . \mathrm{i}$ & $\mathbf{- , 6 1 5}$ \\
\hline Norma etyczna & $\mathbf{- , 3 6 4}$ & $\mathbf{, 0 0 0}^{* *}$ &,- 111 & $\mathrm{n} . \mathrm{i}$ & $\mathbf{- , 4 9 6}$ \\
\hline
\end{tabular}

$* \mathrm{p}<, 05 * * \mathrm{p}<, 01$

Podobne wyniki do grupy zasadniczej uzyskała grupa mężczyzn. Współczynniki korelacji uzyskane $\mathrm{w}$ poszczególnych przypadkach są wyższe, co może świadczyć o tym, że powiązania tych typów religijności z wymiarem aspekt moralny mają charakter mocniejszy niż w przypadku grupy zasadniczej. Natomiast za charakterystyczny należy uznać brak znaczących powiązań pomiędzy analizowanymi zmiennymi w podgrupie kobiet.

\section{Podsumowanie i dyskusja wyników}

Na gruncie amerykańskiej i kanadyjskiej psychologii od lat 80 . XX wie$\mathrm{ku}$ są prowadzone badania nad psychologicznymi uwarunkowaniami postawy wobec kary śmierci (zob. McKelvie i Daoussis 1982; McKelvie 1983; De Vries i Walker 1986; Harvey 1986; Kaplan i Ross 1993-1994; Valliant i Oliver 1997; Watson i Ross; Morris 2003; Robbers 2006). Niniejszy artykuł jest próbą nawiązania do nurtu tych rozważań. Autorów interesuje powiązanie religijności z postawą wobec kary śmierci.

Głównym celem badań i analiz było poszukiwanie związków pomiędzy religijnością a postawą wobec kary śmierci. Wyróżnione wymiary postawy wobec kary śmierci pozwoliły w miarę całościowo uchwycić zakres tej pro- 
blematyki i jednocześnie umożliwiły prześledzenie, który z nich jest przez daną osobę bardziej preferowany.

Analizy statystyczno-psychologiczne opisane w poprzednim rozdziale pozwalają wywnioskować, że w przypadku ogólnej postawy wobec kary śmierci (PWKS - WO) tylko trzy relacje religijne wykazują istotne statystycznie powiązania z tym wymiarem i są to: autonomia, buntowniczość oraz wina - lęk. Świadczy to o tym, że zwolennikami kary śmierci są osoby, które w relacji do Boga są autonomiczne, poszukujące zarówno własnego systemu wartości, jak i drogi, którą będą podążać w życiu. W tym miejscu badania te są zbieżne z badaniami Rossa i Kaplana (1993-1994), którzy wykazali, że osoby charakteryzujące się przekonaniem, iż życie danej osoby należy do niej albo do państwa, a nie do Boga, są zwolennikami stosowania kary śmierci. Jak wynika z badań Śliwaka i Szafrańskiej (2000), osoby, u których przeważa relacja do Boga typu autonomia charakteryzują się niższym stopniem altruizmu. Podobnie zauważa Jarosz (2003, s.135), że osoby charakteryzujące się autonomiczną relacją do Boga mogą być agresywne w relacjach do innych ludzi. Czynnik agresji (jego podwyższony poziom) jest często przytaczany przez badaczy zajmujących się problematyką karania jako wyznacznik aprobaty dla stosowania surowych kar, łącznie z karą śmierci (zob. Mika 1969). Pozytywnie zapatrują się na karę śmierci również osoby, które są krytyczne wobec Boga i buntują się przeciwko Niemu. Badania Śliwaka i Szafrańskiej (2000) pokazały, że również $\mathrm{i}$ ten wymiar negatywnie koreluje $\mathrm{z}$ altruizmem, co w pewnym zakresie może thumaczyć pozytywne ustosunkowanie się wobec kary śmierci ludzi buntujących się przeciw Bogu. Ponadto osoby mające żal do Boga, że nie spełnia ich oczekiwań, charakteryzują się podwyższonym indywidualizmem i mają własne standardy życiowe (por. Jarosz 2003, s. 138), co - jak było już wspomniane wyżej - może być predyktorem pozytywnego ustosunkowania się do kary śmierci. Również osoby odczuwające winę i lęk względem Boga pozytywnie patrzą na karę śmierci. Osoby charakteryzujące się takim typem relacji religijnej postrzegają Boga przede wszystkim lękowo jako niemiłosiernego i surowego sędziego, a co się z tym wiąże - mogą mieć przeświadczenie, że popełnione na ziemi złe czyny powinny być surowo ukarane, w krańcowym przypadku karą śmierci.

Gdy w dokonywanych analizach uwzględni się podgrupy wyodrębnione ze względu na płeć, to okaże się, że u kobiet, podobnie jak w grupie zasadniczej, istnieje pozytywne powiązanie relacji buntowniczość i wina - lęk z postawą wobec kary śmierci. Szczególnie interesujące jest negatywne powiązanie intensywności postawy religijnej z postawą wobec kary śmierci. Można zatem powiedzieć, że im kobiety są bardziej religijne, tym wyrażają bardziej negatywną postawę wobec kary śmierci. W przypadku podgrupy mężczyzn, za charakterystyczny należy uznać brak istotnych powiązań pomiędzy posta- 
wą wobec kary śmierci a religijnością. Na tej podstawie można wywnioskować, że religijność reprezentowana przez mężczyzn w znaczący sposób nie wpływa na ich ocenę kary śmierci. Wyniki te są po części zbieżne z wynikami McKelviego i Daoussis (1982) oraz McKelviego (1983), którzy twierdzili, że mężczyźni w znacznie większym stopniu aprobują zastosowanie kary śmierci niż kobiety.

Wielowymiarowe ujęcie postawy wobec kary śmierci pozwala także na szukanie związku religijności z innymi bardziej szczegółowymi aspektami tej kary.

Poprawa przestępcy. W przypadku wymiaru poprawa przestępcy powiązania istotne statystycznie wystąpiły, podobnie jak w przypadku wyniku ogólnego postawy wobec kary śmierci, w dwóch typach relacji: buntowniczość oraz wina - lęk i są to również związki o charakterze pozytywnym. Podobnie możemy powiedzieć o podgrupie kobiet, gdzie wymiar poprawa przestępcy wiąże się negatywnie $\mathrm{z}$ intensywnością postawy religijnej oraz pozytywnie z buntowniczością i winq - lękiem. Biorąc pod uwagę podgrupę mężczyzn, to ci, którzy w relacji do Boga charakteryzują się buntowniczością, są za stosowaniem kary śmierci, gdyż uświadamia ona (kara śmierci) przestępcy, że jego czyn jest godny potępienia. W tej podgrupie warto jeszcze zwrócić uwagę na to, że osoby, których religijność jest typu personalnego, a relacje do Boga charakteryzują się identyfikacją z Chrystusem jako idealnym człowiekiem i wzorem, są przeciwne karze śmierci w tym aspekcie (uświadomienie przestępcy, że jego czyn jest godny potępienia). Wprawdzie nie odnotowuje się powiązań istotnych statystycznie $\mathrm{w}$ omawianych zmiennych, ale tendencja do powiązań jest wyraźna (religijność personalna $\mathrm{r}=-, 230$; identyfikacja $\mathrm{r}=-, 234$ ). Uzyskane wyniki znalazły potwierdzenie w badaniach Śliwaka i Szafrańskiej (2000) oraz Jaworskiego (1989), którzy stwierdzają, że altruizm jest powiązany z religijnościa personalna i z relacją religijną typu identyfikacja.

Aspekt profilaktyczny. Wymiar ten odnosi się do oceny kary śmierci jako metody na odstraszenie potencjalnych przestępców. Dokonując interpretacji istniejących tu powiązań, narzuca się przede wszystkim to, że prawie wszystkie relacje do Boga (oprócz zależności) łączą się pozytywnie z tym aspektem (profilaktycznym) kary śmierci. Związki te dotyczą zarówno pozytywnych, jak i negatywnych relacji z Bogiem. Za karą śmierci mającą walor odstraszający opowiadają się zarówno osoby, których stosunek do Boga jest niezależny, buntowniczy czy lękowy, jak i ci, dla których Chrystus jest idealnym wzorem i normą etyczną. Taki rozkład wyników nie jest do końca zrozumiały. Gdy jednak spojrzy się na współczynniki korelacji w podgrupach wyodrębnionych ze względu na płeć, wyniki te stają się chyba bardziej zrozumiałe, gdyż powiązania analizowanych zmiennych wśród kobiet i mężczyzn są zupełnie różne; powiązania w grupie zasadniczej pochodzą w pewnych wymiarach od kobiet, 
a w innych od mężczyzn. O ile kobiety wykazują powiązania aspektu profilaktycznego kary śmierci z autonomia, buntowniczościa i lękiem, to w podgrupie mężczyzn te powiązania są z identyfikacją, współhumanitarnością i normą etyczną. Wprawdzie zarówno u kobiet, jak i u mężczyzn odnotowuje się powiązanie aspektu profilaktycznego z intensywnością postawy religijnej, u kobiet jednak jest to powiązanie negatywne, a u mężczyzn pozytywne. Kobiety, które charakteryzują się wysoką intensywnością pozytywnej postawy religijnej, będą zatem negatywnie oceniały karę śmierci z punktu widzenia profilaktycznego. Uzyskane tutaj wyniki w podgrupie kobiet potwierdzają inne badania. Prężyna (1981) pisze, że osoby z wysoką intensywnością pozytywnej postawy religijnej są otwarte na drugiego człowieka, dostrzegają jego sprawy, problemy i wczuwają się w jego przeżycia. Autor ten pisze dalej, że wrażliwość na sprawy drugiego człowieka - na „ty” stwarza podatny grunt dla odnalezienia „Ty” religijnego. W innych badaniach (por. Śliwak 1993; Śliwak i Szafrańska 2000) okazało się, że osoby preferujące w relacjach z Bogiem autonomię, buntowniczość i lęk są mniej altruistyczne, mniej wrażliwe na drugiego człowieka. Jak wynika z prezentowanych tutaj badań, zupełnie inaczej do tego problemu podchodzą mężczyźni. Za bardzo charakterystyczne, chociażby w odniesieniu do podgrupy kobiet, należałoby uznać to, że wśród mężczyzn stwierdzono, iż pozytywne relacje do Boga (identyfikacja, wspóthumanitarność, norma etyczna, intensywność postawy religijnej) wykazują pozytywne powiązania z karą śmierci w wymiarze profilaktyka. Okazuje się zatem, że dla mężczyzn Bóg może być bardzo ważny, może być wzorem osobowym i normą absolutną, ale zapewnienie pewnego ładu na ziemi należy do człowieka, dlatego osoby łamiące usankcjonowany prawnie porządek, powinny być karane przez państwo, łącznie z karą śmierci.

Zadośćuczynienie społeczeństwu. Wymiar ten odnosi się do oceny kary śmierci pod kątem jej zdolności do przywrócenia zburzonego przez przestępcę ładu i porządku w społeczeństwie, a jednocześnie jej właściwości jako formy odpłaty społeczeństwu za wyrządzone krzywdy. W grupie zasadniczej tylko negatywne relacje z Bogiem (autonomia, buntowniczość, wina - lęk) wykazują statystycznie istotne powiązanie z tym wymiarem kary śmierci. Gdyby zatem zastosować wcześniejsze rozumowanie, że osoby próbujące uniezależnić się od normatywnej funkcji Boga, czy osoby lękliwe i buntujące się w relacjach do Boga, są bardziej za karą śmierci, to wyjaśniałoby to uzyskane tutaj wyniki, a zarazem potwierdzało wyniki innych badań (por. Hutsebaut1980, Śliwak 1993, Śliwak i Szafrańska 2000, Śliwak i in. 2011). Hutsebaut (1980) twierdzi, że osoby, które mają dobre relacje z innymi ludźmi, są przyjacielskie i nastawione prospołecznie, dostrzegają trudne sprawy i problemy innych ludzi.

W podgrupie kobiet widać bardzo wyraźnie, że religia jest czynnikiem, który bez względu na okoliczności zabrania odbierać drugiemu człowiekowi 
życie, nawet w imieniu prawa i nawet wówczas, gdy ten człowiek jest groźnym przestępcą. Kobiety $\mathrm{z}$ wysoką intensywnością pozytywnej postawy religijnej i z religijnością personalną uznają, że motywacja odebrania komuś życia, aby zadośćuczynić przestępcy, jest niewystarczająca w kontekście nakazów ich religii. Można zatem powiedzieć szczególnie w odniesieniu do kobiet, że podobnie jak we wszystkich dotąd omawianych wymiarach, wraz ze wzrostem religijności, kara śmierci jest coraz bardziej negatywnie oceniania jako czynnik służący sprawiedliwej odpłacie społeczeństwu za popełnione czyny. Jest to zapewne spowodowane tym, że kobiety nie posługują się w swoim życiu prawem odwetu: „oko za oko, ząb za ząb”. Jednocześnie mogą poszukiwać one bardziej humanitarnych form karania, wierząc w możliwość zmiany przestępcy. Negacja zastosowania kary śmierci, jako formy zadośćuczynienia społeczeństwu, może także wynikać z tego, że kobiety są bardziej tolerancyjne i altruistyczne. W przestępcy cały czas widzą człowieka, który mimo że dopuścił się przestępstwa, nie stracił w ich oczach przymiotu ludzkiego. Akceptacja kary śmierci jako czynnika służącego zadośćuczynieniu oraz przywróceniu ładu i porządku w grupie kobiet może wynikać z obranego systemu wartości i ukształtowanych relacji do Boga, jakimi są buntowniczość oraz przeżywanie przez kobiety lęku w kontaktach z innymi osobami. Odczuwanie lęku, może przekładać się na brak zaufania do innych niż kara śmierci form resocjalizacji. U mężczyzn akceptowanie kary śmierci jako czynnika służącego odpłacie społeczeństwu za wyrządzone zło wiąże się z pozytywnymi relacjami do Boga (zależność i wyraźna tendencja do powiązań istotnych statystycznie we wspóthumanitarności i normie etycznej). Stwierdzone zależności w podgrupie mężczyzn ponownie dowodzą, że powiązania między analizowanymi zmiennymi inaczej wyglądają u kobiet, a inaczej u mężczyzn.

Aspekt moralny. Wymiar ten wyraża zdolność odnajdywania w swojej wierze argumentów natury moralnej i etycznej usprawiedliwiających zastosowanie kary śmierci.

Wymiar ten charakteryzuje się największą liczbą istotnych powiązań i są to powiązania najsilniejsze. Na dziewięć analizowanych aspektów religijności siedem wykazuje powiązania istotne statystycznie i są to wszystko powiązania o wysokim współczynniku (r) i bardzo wysokim poziomie istotności (w dwóch przypadkach $\mathrm{p}<.001$, w pozostałych $\mathrm{p}<.000$ ). Po analizie wyników uzyskanych w tym wymiarze można zauważyć, że osoby religijne, które w swoich relacjach z Bogiem charakteryzują się aktywnością, a ich system poznawczy jest otwarty na nowe doświadczenia $\mathrm{i}$ wiadomości, nie potrafią z moralnego punktu widzenia usprawiedliwić zastosowania kary śmierci. Kiedy natomiast relacje z Bogiem mają charakter negatywny, krytyczny i buntowniczy, wtedy taka osoba potrafi odnaleźć w swoich przekonaniach takie argumenty, które pozwalają na jej zastosowanie. W tym miejscu prowadzone badania są zbież- 
ne z wynikami uzyskanymi przez De Vriesa i Walkera (1986) oraz Harveya (1986), w których postulowali oni, że osoby charakteryzujące się niedojrzałym systemem moralnym, oraz u których system poznawczy jest mało otwarty i bardziej arbitralny, są zwolennikami stosowania kary śmierci. W podgrupie kobiet za charakterystyczny można uznać brak jakichkolwiek istotnych powiązań pomiędzy religijnością a tym wymiarem kary śmierci. Jeżeli chodzi o grupę mężczyzn, powiązania występują w siedmiu z dziewięciu mierzonych typów religijności, czyli tak samo jak w grupie zasadniczej i dotyczą tych samych wymiarów. Uzyskane wyniki wskazują na to, że mężczyźni o wysokiej intensywności pozytywnej postawy religijnej (wysoka religijność) nie potrafią w swojej wierze znaleźć argumentów, które pozwoliłby zastosować karę śmierci. Podobna sytuacja ma miejsce w przypadku mężczyzn, których religijność jest aktywna, otwarta, a oni sami są bardziej tolerancyjni. Tolerancja, którą te osoby wynoszą ze swojej religijności, jest u nich projektowana na życie codzienne, a co za tym idzie - nie mają oni tendencji do stosowania praw odwetu, jak jest w przypadku mężczyzn nietolerancyjnych. To że mężczyźni przeżywają pozytywne relacje z Bogiem, jest w przypadku tego wymiaru wyznacznikiem moralnej dezaprobaty dla stosowania kary śmierci. W przypadku natomiast relacji negatywnych, w szczególności związanych z krytycznym i buntowniczym ustosunkowaniem się do Boga, możemy powiedzieć, że takie osoby mają z moralnego punktu widzenia możliwość usprawiedliwienia kary śmierci. Można zauważyć, że w grupie mężczyzn wymiar ten odgrywa ważniejszą rolę niż w grupie kobiet.

Reasumując, można powiedzieć, że dokonane zestawienie wyników, związków wymiarów postaw wobec kary śmierci z typami religijności, ze szczególnym uwzględnieniem płci, można potraktować jako wkład w obecny w literaturze problem różnic w zakresie postaw wobec kary śmierci (por. McKelvie i Daoussis 1982; McKelvie 1983; Robbers 2006). Analiza wyników niniejszej pracy pozwala dosyć jednoznacznie stwierdzić, że istnieją powiązania między analizowanymi zmiennymi, tzn. postawą wobec śmierci a religijnością. W ten sposób zweryfikowana została hipoteza pierwsza (H 1), mówiąca o takich powiązaniach. Można powiedzieć, że tylko częściowo potwierdziła się hipoteza druga (H 2), która wskazywała, że wysokiej intensywności pozytywnej postawy religijnej towarzyszy negatywna postawa wobec kary śmierci. Sprawdziło się to, ale tylko w odniesieniu do grupy kobiet i to nie tylko w wyniku ogólnym, lecz także w trzech wymiarach, takich jak: poprawa przestępcy, aspekt profilaktyczny i zadośćuczynienie społeczeństwu. W grupie zasadniczej i podgrupie mężczyzn hipoteza ta potwierdziła się tylko w wymiarze aspektu moralnego kary śmierci. W aspekcie profilaktyka przestępcy mężczyźni uzyskali wynik odwrotny do stawianej hipotezy. Trzecia hipoteza (H 3) też nie uzyskała jednoznacznej weryfikacji. Jeżeli chodzi o wynik ogólny kary śmier- 
ci, to nie stwierdzono żadnej istotnej statystycznie zależności z religijnościq personalną. Zależność taką odnotowano w przypadku takich wymiarów kary śmierci, jak zadośćuczynienie społeczeństwu (zależność o charakterze ujemnym, istotna statystycznie dotyczy grupy kobiet), a jeszcze bardziej wyraźną zależność w aspekcie moralnym kary śmierci (grupa zasadnicza i podgrupa mężczyzn uzyskuje negatywny współczynnik istotny statystycznie). $\mathrm{W}$ istocie rzeczy religijność personalna wiązała się $\mathrm{w}$ tych przypadkach $\mathrm{z}$ brakiem akceptacji dla kary śmierci. Czwarta hipoteza (H 4) sugerowała, że osoby preferujące negatywne relacje w stosunku do Boga, takie jak: buntowniczość czy autonomia, będą raczej zwolennikami kary śmierci. Można uznać, że hipoteza ta potwierdziła się w tym przypadku, gdy była mowa o ogólnej postawie wobec kary śmierci i w odniesieniu do grupy zasadniczej. Znajduje ona jeszcze częściowe potwierdzenie w podgrupie kobiet i raczej nie weryfikuje się w podgrupie mężczyzn, gdzie nie odnotowano żadnych istotnych powiązań między omawianymi zmiennymi. Jeżeli natomiast chodzi o wymiary kary śmierci, to hipoteza ta znajduje najsilniejsze potwierdzenie w wymiarze zadośćuczynienie społeczeństwu i aspekcie profilaktycznym (oprócz podgrupy kobiet), a słabsze potwierdzenie (powiązanie tylko z buntowniczościa) w wymiarach poprawa przesteppy i aspekt moralny. Ostatnia hipoteza (H5) sugerowała, że płeć modyfikuje powiązania między analizowanymi zmiennymi. Ta hipoteza znalazła potwierdzenie w prezentowanych badaniach. W wielu przypadkach obraz powiązań w podgrupie kobiet był różny niż w podgrupie mężczyzn. Kobiety religijne zdecydowanie bardziej negatywnie niż mężczyźni wypowiadają się na temat kary śmierci. Świadczyć o tym może obecność negatywach powiązań z intensywnościa postawy religijnej oraz religijnościa personalna. Natomiast w przypadku kobiet, u których relacje z Bogiem są nacechowane chęcią poszukiwania własnych systemów wartości, krytycznym ustosunkowaniem się do Niego oraz odczuwaniem lęku, można zauważyć pozytywne ustosunkowanie się do kary śmierci. Analiza uzyskanych wyników pozwala stwierdzić, że kobiety inaczej niż mężczyźni, oceniają karę śmierci. W przedstawionym zestawieniu można zauważyć, że w niektórych wymiarach więcej jest powiązań z wynikami kobiet, a w innych - więcej powiązań w grupie mężczyzn. Za „kobiecy” wymiar można uznać ogólna postawę wobec kary śmierci oraz zadośćuczynienie społeczeństwu. „Męskim” wymiarem jest natomiast zdecydowanie aspekt moralny. Analiza treści wymiarów pozwala stwierdzić, że kobiety przywiązujące wagę do własnej religijności będą zdecydowanymi przeciwniczkami kary śmierci. Z drugiej jednak strony, wymiary te pozwalają wywnioskować, że w przypadku kobiet, dla których religia nie stanowi wartości, mamy do czynienia $\mathrm{z}$ akceptacją kary śmierci. Jeżeli natomiast chodzi o „męski” wymiar, można zauważyć, że mężczyźni, wartościujący wysoko 
religijność oraz respektujący prawa i nakazy Boga nie są w stanie odnaleźć moralnych przesłanek, które usprawiedliwiałyby stosowanie kary śmierci.

\section{STRESZCZENIE}

Celem prezentowanych $\mathrm{w}$ tym artykule analiz było poszukiwanie powiązań pomiędzy religijnością a postawą wobec kary śmierci. Problem badawczy można oddać w pytaniu: Czy istnieje zależność pomiędzy religijnością a postawą wobec kary śmierci? W artykule sformułowano pięć hipotez i w celu ich weryfikacji zastosowano następujące narzędzia badawcze: Skalę Intensywności Postawy Religijnej - W. Prężyny, Skalę Relacji do Boga - D. Hutsebauta, Skalę Religijności Personalnej - R. Jaworskiego oraz Kwestionariusz Postaw wobec Kary Śmierci - w opracowaniu autorów artykułu. Ogółem przebadano 100 osób, wśród nich było 55 kobiet oraz 45 mężczyzn. Średni wiek wyniósł $31,59(\mathrm{SD}=9,01)$. Analiza wyników niniejszej pracy pozwala dosyć jednoznacznie stwierdzić, że istnieją powiązania między analizowanymi zmiennymi, tzn. postawą wobec kary śmierci a religijnością. Pozostałe hipotezy potwierdziły się tylko częściowo. W wielu przypadkach obraz powiązań w podgrupie kobiet był różny niż w podgrupie mężczyzn.

Słowa kluczowe: postawa religijna; typ religijności; postawa wobec kary śmierci

\section{RELIGIOSITY AND THE ATTITUDE TO DEATH PENALTY}

\section{SUMMARY}

The main purpose of the analysis presented in this paper is to search for connections between religiosity and the attitude to death penalty. The paper focuses on the question: is there any connection between one's religiosity and his (her) attitude to death penalty. The general assumption was that there is some connection between these variables. To verify the hypotheses that had been assumed, 100 respondents ( 55 women and 45 men) were tested by the following methods: The Scale of Relationship to God by D. Hutsebaut, the Religious Attitudes Scale by W. Prężyna, The Scale of Personal Religiousness by R. Jaworski and Scale of Attitudes to Death Penalty by Śliwak, Korczyński. The findings confirmed the main assumption that there is a connection between variables. Others hypotheses were partially confirmed. Some differences were observed between the group of men and the group of women.

Keywords: religious attitude; type of religiosity; attitude to death penalty 


\section{BIBLIOGRAFIA}

Bartula P. (1998 a): Kara śmierci - powracający dylemat. Kraków.

Bartula P. (1998 b): Podważanie abolicjonizmu w 12 punktach. W: E. Nowicka-Włodarczyk (red.), Kara śmierci s. 13-25. Kraków.

Beccaria C. (1959): O przestępstwach i karach. Warszawa.

Bronk A. (1996): Nauka wobec religii. Lublin.

Chaim W. (1991): Psychologiczna analiza religijności niespójnej. Lublin.

Chudy W. (1989): Przeciwko karze śmierci. Argumenty filozoficzne. „Ethos” 2 nr 5 (1) s.147-152.

De Vries B., Walker L.J. (1986): Moral reasoning and attitudes toward capital punishment. „Developmental Psychology" 22 s. 509-513.

Donohue J.J., Wolfers J. (2006): Uses and Abuses of Empirical Evidence in the Death Penalty Debate. „Stanford Law Review” t. 58 z. 3 s. 791-841.

Grześkowiak A. (1982): Kara śmierci w polskim prawie karnym. Toruń.

Grześkowiak A. (1988): Wspótczesne problemy kary śmierci. „Przegląd Powszechny” 1 s. 23-37.

Harvey O.J., (1986): Belief systems and attitudes toward the death penalty and other punishment. „Journal of Personality” 54 s. 659-675.

Hutsebaut D., (1980): Belief as livd relations. „Psychologica Belgica” 20 s. 33-47.

Jarosz M. (2003): Interpersonalne uwarunkowania religijności. Lublin.

Jaworski R. (1989): Psychologiczne korelaty religijności personalnej. Lublin.

Kłoczkowski J. (2003): Akt religijny. W: Religia. Encyklopedia PWN. T. 1. Wyd. zbiorowe. Warszawa.

Krahé B. (2005): Agresja. Gdańsk.

Kuczkowski S. (1993): Psychologia religii. Kraków.

Makselon J. (1990). Psychologia dla teologów. Kraków.

McKelvie S.J., Daoussis L. (1982): Extraversion and attitude towards capital punishment. „Personality and Individual Differences" t. 3 z. 3 s. 341-342.

McKelvie S.J. (1983): Personality and belief in Capital Punishment: a replication and extension. „Personality and Individual Differences” t. 4 z. 2 s. 217-218.

Mika S. (1969): Skuteczność kar w wychowaniu. Warszawa.

Pastuszka J. (1964): Osobowość a religijność człowieka. Analiza psychologiczna. „Roczniki Filozoficzne" 12 z. 4 s. 5-16.

Prężyna W. (1981): Funkcja postawy religijnej w osobowości człowieka. Lublin.

Prężyna W. (1973): Intensywność postawy religijnej a osobowość. Lublin.

Prężyna W. (1968): Skala Postaw Religijnych. „Roczniki Filozoficzne” 4 s. 75-90.

Prokopiuk J. (1968): Szkice z psychologii religii. Warszawa.

Robbers M. (2006): Personality traits as predictors of attitudes toward the death penalty - an exploratory gendered study. „Punishment \& Society” t. 8 nr 2 s. 203-222.

Ross L.T., Kaplan K.J. (1993-1994): Life ownership orientation and attitudes toward abortion, suicide, doctor-assisted suicide, and capital punishment. „Omega” 28 s. 17-13.

Szostek A. (1989): Nie będziesz zabijat (Wj 20,13). „Ethos” 2 nr 5(1) s. 137-146.

Śliwak J. (1993): Altruizm a religijność człowieka. Badanie empiryczne, „Roczniki Filozoficzne” 41 z. 4 s. $53-78$.

Śliwak J. (2005): Religijne style poznawcze a postawa wobec śmierci. W: J. Makselon (red.), Człowiek wobec śmierci. Kraków.

Śliwak J., Szafrańska M. (2000): Poziom altruizmu a przeżywane relacje religijne do Boga. W: T. Doktór, K. Franczak (red.), Postawy wobec relgii. Psychologiczne uwarunkowania i konsekwencje s. 161-185. Warszawa.

Śliwak J., Bartczuk R. (2011): Skala Przeżywanych Relacji Religijnych D. Hutsebauta. W: M. Jarosz (red.), Psychologiczny pomiar religijności s. 171-200. Lublin. 
Śliwak J., Zarzycka B., Rak R. (2011): Kryzys $w$ wartościowaniu a relacje religijne. „Czasopismo Psychologiczne" 17,1 s. 75-86.

Valliant P.M., Oliver C.L. (1997): Attitudes toward capital punishment: a function of leadership style, gender and personality. „Social Behavior and Personality” 25 s. 161-168.

Wandrasz M. (1998): Religijność a postawa wobec choroby. Lublin.

Watson P.J., Ross D.F., Morris R.J. (2003): Borderline personality traits correlate with Death Penalty decision. „Personality and Individual Differences” t. 35 z. 3 s. 421-429.

TOMasz KorCZYŃsKI - mgr, kapitan, starszy psycholog Działu Penitencjarnego Zakładu Karnego w Opolu Lubelskim; prowadzi zajęcia na Katolickim Uniwersytecie Lubelskim Jana Pawła II w Lublinie; e-mail: Tomasz.Korczynski@sw. gov.pl.

JACEK ŚLIWAK - dr hab. nauk humanistycznych, profesor Katolickiego Uniwersytetu Lubelskiego Jana Pawła II w Lublinie, kierownik Katedry Psychologii Społecznej i Psychologii Religii w Instytucie Psychologii Katolickiego Uniwersytetu Lubelskiego Jana Pawła II w Lublinie; e-mail: sliwak@kul.lublin.pl. 